\title{
Sámi (re)presentation in a differentiating museumscape: Revisiting the art-culture system
}

\author{
Monica Grini
}

\begin{abstract}
The article addresses how Sámi culture is presented by museums in Oslo. One of the findings is that the old binary of "art" and "ethnographica" is still common in this museumscape. This reflects the historical divide between the art museum showing "European" and "Norwegian" art, and the ethnographic museum showing the arts of "the rest". It is argued that Sámi artists, works, themes, and practices have had difficulties entering the reservoir of Norwegian "national imagery" and that such predicaments reflect persistent investments in the narrative of Norway as a monocultural nation.
\end{abstract}

Keywords: Art-culture, dáidda, duodji, museumscape, representation, articulation, Sámi, Norwegian.

This article takes its initial cue from the 2012 Bååstede-report. The report is the principal document guiding what is framed as a repatriation process, where around two thousand objects are to be relocated to Sápmi, that is, in what is defined as Sámi museums in the Norwegian part of the vast, transnational Sámi area. At the same time as the report's primary focus is on the repatriation process, it underscores that "it lies in this project a clear acknowledgment that Sámi history is to be communicated by museums in Norway, not only by Sámi museums" (Bååstede 2012:34, my translation). The report especially foregrounds that museums in Oslo should have a "good and representative presentation of Sámi culture" (Bååstede 2012:9, my translation). This statement sparked curiosity: How is "Sámi culture" presented in the museological landscape of today's Oslo?

Although a seemingly straightforward question, it needs some interpretation to be operative. For example, what can "good and representative presentation" mean, and what does "Sámi culture" refer to? Seen from a pragmatic perspective, the meaning of concepts are to be found in the context of their use. The Bååstede-report does not specifically state what is intended by "Sámi culture", but the report highlights various objects - from a náhppi, a reindeer milk bowl, to a richly decorated purse, or a batlet for preparing 
senna grass, used for lining footwear during wintertime - as well as Sámi language and knowledge. In other contexts, notions like art, duodji, dáidda, craft, music, theatre, literature and traditional husbandry are activated when describing "Sámi culture" (Gaski \& BergNordlie 2019). Suffice to say, a survey of various uses would probably show that the concept is held together by sets of (overlapping and changeable) family resemblances, and not reducible to one essential common feature.

\section{Culture And articulation}

The concept of culture has long been contested. It is "one of the most difficult, richly connotative concepts to define" (Cobley 2008). Its parentage is disputed (although the root is commonly seen to lie in the Latin verb colere, which can be translated "to cultivate"), a demarcation is sometimes made between a humanist and an anthropological usage of the term. ${ }^{1}$ The first usage is often considered evaluative, hierarchical and singular, denoting something similar to the outdated "civilization", recognizable for example in the Norwegian word finkultur (denoting "highbrow culture" or "arts"). The second usage is perceived as fundamentally relativistic, indicating something that is to be found in every human society and that makes the particular society recognizable in a certain way (e.g. Stocking 1966; Bennet 2015). But as Stocking points out, as most antitheses, it "breaks down partially when proved" (1966:68); for example, both uses centre around the human and tend to imply a dualistic position to "nature" (e.g. Latour 1993; Blaser 2009). Also, there are frequent travels between the permeable disciplinary boundaries of art and anthropology, whether one refers to the university or the museum setup. Still, or in spite of such translations, the use of "culture" perceived as "arts", and "culture" perceived as something like "elements that help distinguishing one society from another" is prevailing, even if the uses are overlapping and intertwined, and cannot automatically be reduced to a matter of either/or.

To help navigate such entanglements, my approach is informed by a notion that sees "culture" as something that can be activated in different forms, by different means in different context by different actors (e.g. Grossberg 1986; Clifford 2013). Thus, it has been important to keep the analytical focus open enough to grasp the full range of possible articulations. I have been tracking what has been directly articulated as Sámi matters, for example, through wall texts and other communicative devices in different museums, but I have also been on the lookout for more indirect or implicit Sámi relations that are not necessarily activated as such in the museums in question, but by other actors in other contexts, as for example indicated by the Båastede-report or by Sámi institutions. Also, it is important to underscore that meaning and agency is, of course, not only manifested through language; for example, the Sámi flag is as strong an indicator and effector of Sámi presence, or gesture towards the autonomy of a "we", or "a culture", as any museum wall text.

Furthermore, by talking about museumscapes, this article pays attention to the ways in which museums may operate collectively, and to the effects of that operation when it comes to Sámi representation in Oslo. Like Sharon Macdonald has pointed out, museums do labour, not only through the content of each museum - through what they individually collect and exhibit, the modes of display and other choices made - but also through their very presence in a greater museological landscape. They work in concert, through "divisions 
of classificatory labour and hierarchies of value between kinds of museums, and their locations within cities and within nations" (2016:4). In this perspective, it is an ambition to pay effort, not only to Sámi articulations, but the to the whole variety of articulations and emplacements in the various museums to see what each attend to, what is collected and exhibited where, how it is exhibited, and under what labels.

\section{Situating The MUSEUMSCAPE}

About 200 years ago, when the small province city of Christiania, now Oslo, was to become the capital city of the newly established Norwegian national state, a major axis was drawn from the incipient castle on the hilltop towards the flat stretch of land where the parliament was to be built. On both sides of this "axis of power" other institutions of exceptional national significance were to be constructed; the national theatre on one side and the university on the other. Carefully related to this main bloc, creating a precise right-angle "from the dome of the theatre throughout the assembly hall of the university", the National Gallery took form (Butenschøn 2015).

On the opposite side of the National Gallery, facing the castle, is the Historical Museum. It houses the University's Museum of Cultural History, a merger encompassing the collections of Norwegian and classical antiquities (Universitetets Oldsaksamling, 1811), the coin cabinet (1817), and the ethnographic collections (former Ethnographic Museum, 1853). The National Gallery is at the moment being emptied while preparing for a new National Museum of Art, Architecture and Design at the refurbished waterfront part of Oslo, scheduled to open in 2021. This umbrella-institution was established in 2003 by the merging of the aforementioned National Gallery (founded in 1837), the Museum of Decorative Arts and Design (founded in 1876), the Museum of Architecture (founded in 1975) and the Museum of Contemporary Art (founded in 1988), although remaining in separate institutions until the present relocation.

Located on the Bygdøy peninsula, in a bucolic area away from the city centre, is the Norwegian Museum of Cultural History (Norsk Folkemuseum), established in 1894. It is a large open-air museum accommodating buildings from rural and urban Norway from the middle ages to the 20th century, as well as a large collection of artefacts. Here too is a royal connection, as the museum encompasses the Bygdø Royal Manor, presently a summer residence used by H.M. King Harald.

It is not the intention here to give a fullfledged account of all museums situated in Oslo, but simply to pinpoint some of the main nodes in the museological landscape of the city and to accentuate them as powerful spaces, also with regard to their actual locations. The museums mentioned can all be said to be spaces that feature prominently, not only in Oslo, but on a national museum scene at large. Positioned in the capital and resting heavily on public funding, they are intended not only to be of importance for inhabitants there, but for all the citizens, also for those who never visit them. The museums can be described as parts of the mainstream national repertoire; they form segments of institutions that a nation-state is expected to have, not only for interior reasons, but also with regard to demarcation between national states. Moreover, they are of special interest for the question posed here, as designated museums for arts and culture, whether humanist or anthropological uses of the concepts are brought to mind. 


\section{ENCOUNTERING THE NATIONAL IMAGINARY}

The building that houses the National Gallery can be described as a monument in miniature, fitting for the burgeoning small-scale capital at the time it was built. It is moulded over a renaissance concept, already proven on a grander scale in other art museums in the early 19th century, like the Alte Pinakothek in München, evoking historical connotations intended to match the building's function (e.g. Hvattum 2017).

As customary in museums with significant collections, the audience is able to see parts of its possessions in a so-called permanent exhibition. The latest version, The Dance of Life: The Collection from Antiquity to 1950, was on display from 2011 until the museum finally closed its doors in mid-January 2019 only interrupted by the 2013 sesquicentennial celebration of Edvard Munch's birth. I first visited the display in 2012 with the aim to systematically map Sámi presence in the National Gallery, followed by later revisits where only minor changes were to be found.

Moving up the marble stairs to the main halls, I was met with Christian Krohg's grand painting Leiv Eirikson discovering America (1893), flanked on either side by Albertine to see the police surgeon (1887) and Struggle for survival (1889). While the latter paintings are thematising contemporary social issues, the first-mentioned - painted for the Chicago's 1893 world's fair - is pairing Krohg's celebrated realism with a theme more connected to national romanticism. The style is naturalistic, the men's appearance not particularly idealized. Leiv Erikson and his crew are depicted with rugged, ruddy faces and thinning hair, and strong diagonals and abrasive pencil strokes add to the realistic feeling, whereas details like the large knife hanging from Erikson's belt and the presence of the polished Viking helmet and axe reflect the heroic nationalistic undertow of the subject, without doubt carefully selected for an event like the world's fair. The inclusion and placement of the image - the first thing encountered when entering the exhibition - is, of course, equally as much a strategic move by the curators of today.

Easel paintings from the 19th and 20th century continue to dominate the exhibition, reflecting the importance of this medium for national art galleries and art history in general, and mirroring a central epochal focus in Norwegian art history. National icons like Adolph Tidemand and Hans Fredrik Gude's national romantic Bridal Procession on the Hardangerfjord (1848), seem to be routinely included in every basis exhibition. The work has been criticised from an authenticating perspective; for not showing "real Norwegians", nor an accurate landscape - it was painted in the artists' studio in Düsseldorf, using German models, and is based on a combination of sketches from observations of nature in various regions of Norway combined into one. Thus, it does not show one "true" place. Still, or precisely because of that, because they sort of condense and reinforce a designated national imagery, it can be argued that such pictures have played a crucial role in "making the nation real", to say it with Anthony D. Smith (2013), in inducing people to "see the nation" and make them assign to the national project.

Artists like Tidemand and Gude, among many others artists in the 19th century, seem to have had a genuine interest in mapping and articulating what they perceived as interesting characteristics connected to the realm now known as the Norwegian national-state. The Danish-Norwegian artist, Johannes Flintoe, is often presented as the one who "showed 


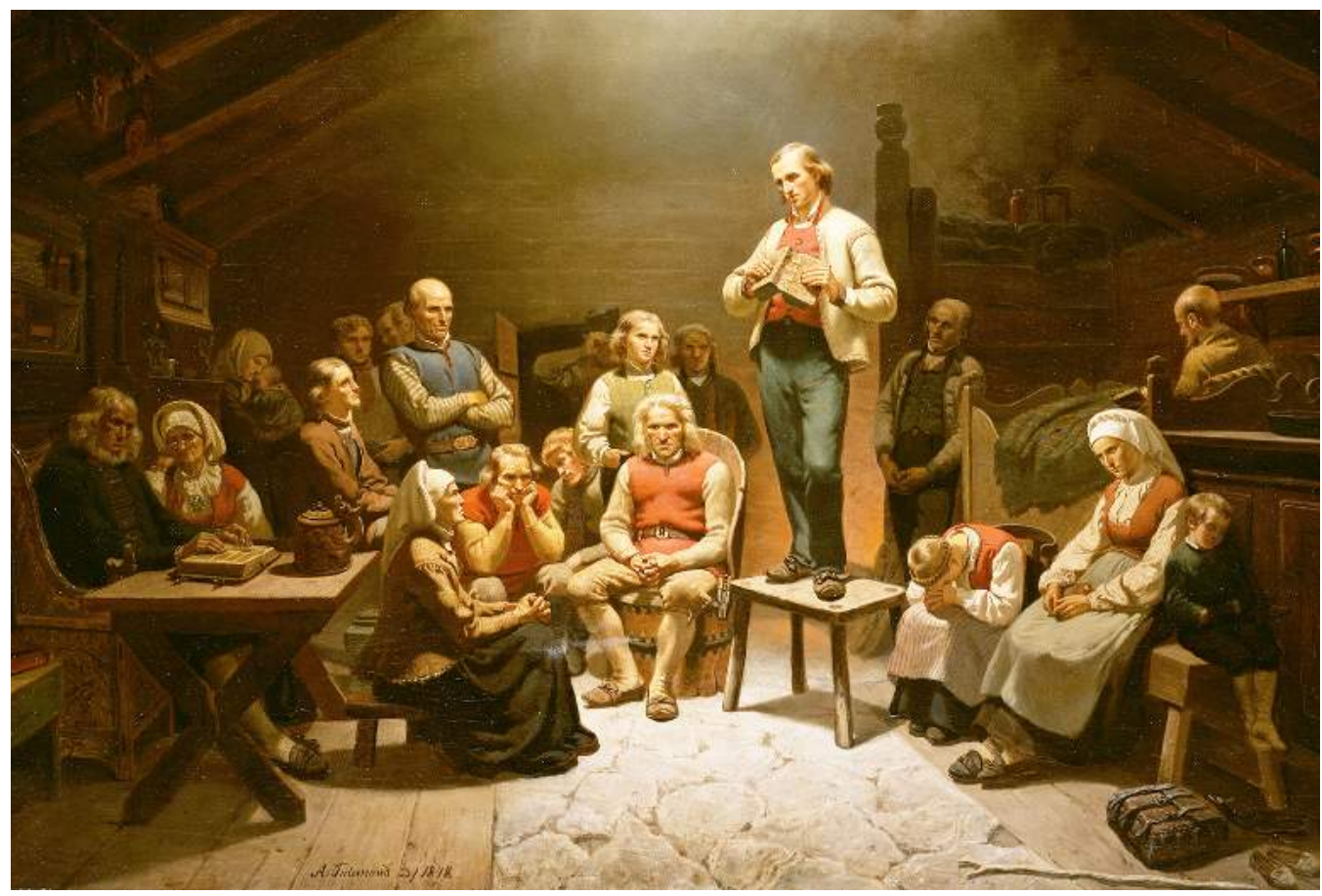

Fig.1. Adolph Tidemand, Low Church Devotion, 1848. Oil on canvas. The National Museum of Art, Arc hitecture and Design, Oslo. Photo: Jaques Lathion.

the Norwegians the way to the Norwegian highlands" (Nasjonalmuseet 2019 a). As a Dane, born and raised in Copenhagen, but with a father from the Norwegian part of the empire, the mountainous part of the country interested him. Beginning his extensive travels over the inland south eastern and western mountain massifs in 1819 , his journeys and the studies from them became roadmaps for later surveyors, like Johan Christian Dahl, or the aforementioned Tidemand and Gude.

Although the majority of the artist followed the well-trodden path between the southeast and western parts of Norway, the northern part of the country and Sámi traditions were of interest for artists at the time. For instance, Hans Johan Fredrik Berg, born in Nordland, is well represented in the National Museums's collection. For example, with portraits of named Sámi individuals, like the pastel drawings of Kari Johnsdatter (1874) or Lars Olsen (1870), just to name a few of the works representing Sámi subjects. Even Flintoe, includes people with Sámi attire in his "documentation" of national costumes in a picture, not on display, but in the gallery's collection (e.g. Grini \& Oskal 2018). None of the representations, whether they are meant to articulate "Norwegian" or "Sámi" culture, capture the "whole picture", they simplify and accentuates what was considered most characteristic. Furthermore, some tend to follow an ideological hierarchical configuration, depicting the Norwegian farmer as simple living, but "noble", and the 


\section{Monica Grini}

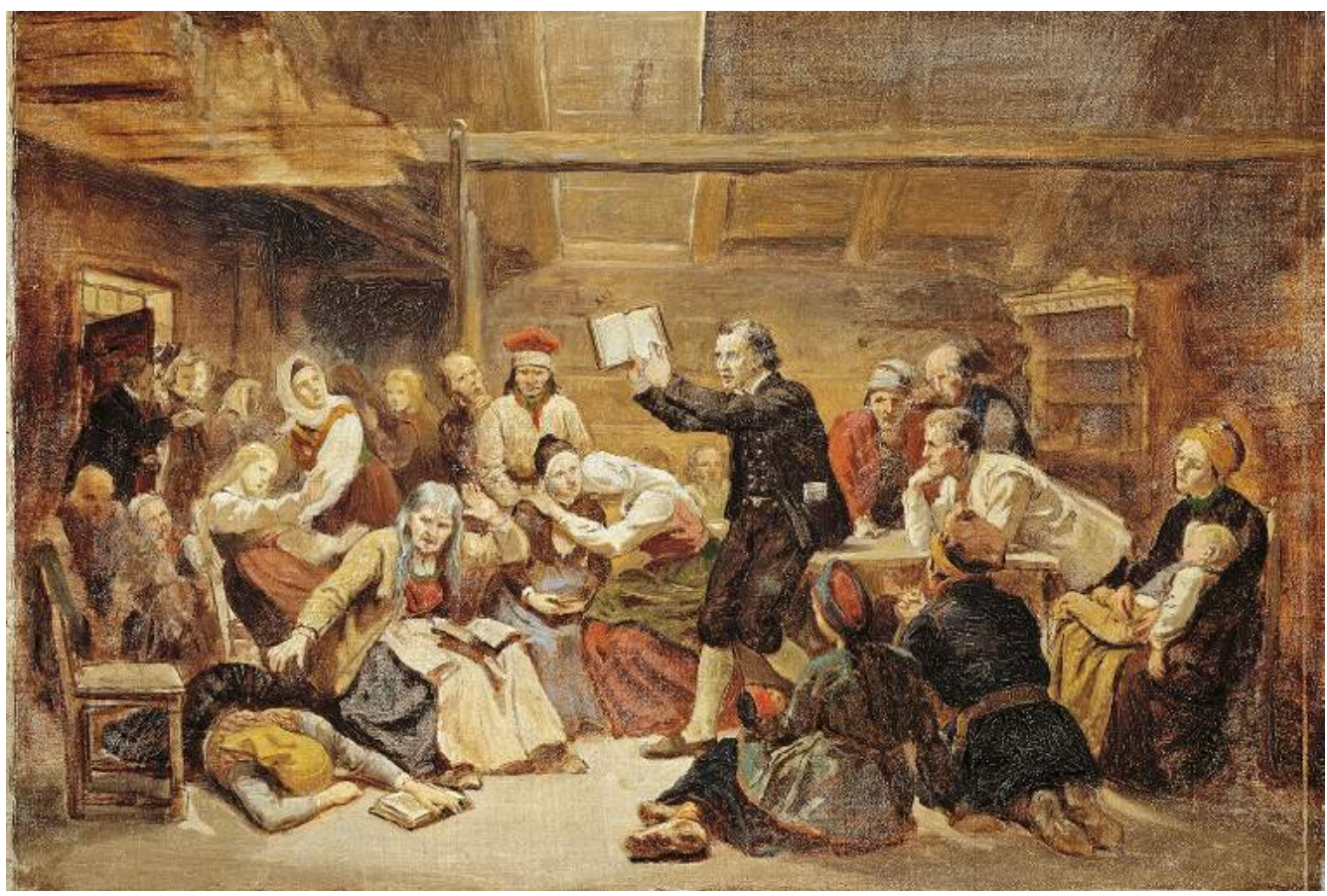

Fig. 2. Adolph Tidemand, The Fanatics, 1865-1866. Preparatory oil sketch. The National Museum of Art, Architecture and Design, Oslo. Photo: Jaques Lathion.

Sámi as poor, and rustically living, "ignoble" (e.g. Høydalsnes 2003).

In my view, the Low Church Devotion, 1848, and the Fanatics, 1865-1866, both by Tidemand, in some ways adheres to this structural pattern. The former, on display in the gallery, shows a group of farmers, solemnly contemplating the word of God. They are immersed in a soft, golden light, while the lay preacher, Hans Nielsen Hauge, is standing on a chair, creating a pyramidical composition, an established device for depicting divine subjects. Whereas the latter shows a mixed group of people, among them people in Sámi clothes, arranged in a horizontal composition, many of them expressing strong emotions, accentuated by a flat, white lighting. Notably, the preacher maybe intended to represent the northerner, Lars Levi Læstadius, who was selfidentifying as Sámi and fluent in two Sámi languages; he is not elevated, but shares the floor with his followers. ${ }^{2}$

The museum does not possess the finished version of the Fanatics, it is owned by the Swedish National Museum, but it holds interesting preparatory works, a detailed pen and wash drawing, and an oil sketch. Thus, the absence of the finished painting is not a sufficient reason for not giving the audience a chance to explore the subject further, especially not since an entire room is dedicated to oil sketches from exactly the same period, but none of them depict Sámi subjects. Moreover, it would, of course, be possible to borrow the 
Stockholm Fanatics, which is rarely on display there, to deepen the exploration.

The exhibition is envisioned by the museum as "a journey through art history from antiquity to 1950, with an emphasis on Norwegian art after 1800" (Nasjonalmuseet 2019 b). I embarked on the journey expecting to find, in the least, works by John Savio, born in Finnmark and with a Sámi and Kven background, and of which the museum holds a large collection. ${ }^{3}$ Savio's woodcuts are especially well-regarded, and although the exhibition was dominated by painting, the fact that the curators had included selections of the National Gallery's vast selection of paper works (like drawings, pastels and graphic works), justified my anticipation. Though, scanning the walls and opening the drawers in large filing cabinets placed throughout the exhibition, none of Savio's woodcuts, like Chiermagak (Reindeer Calves), from between 1920-1933, Gánda ja nieida (Boy and Girl) or Okta (Alone), both undated, were to be found. Suffice to say, no imagery connected to Sámi culture was there to punctuate the national imaginary of the National Gallery's basis exhibition, even if the museum has a number of works with Sámi references, or by artists that identify as Sámi, in their collection (Grini 2016:134-139, 246-251; Grini 2019).

\section{IGNORING DUODJI}

While I entered the National Gallery expecting to find Sámi imagery, I reached the Museum of Decorative Arts and Design, no more than a couple of blocks away, hoping to experience the vigorous and overlapping fields of Sámi duodji, design, and fashion.

Duodji is a rich concept, difficult to translate with hegemonic art terms, without meaning being added or removed. It is sometimes referred to in a wide sense as both the ability to do something and to the result of such expertise - the material object or the work. In a narrower sense, duodji is about a particular Sámi practice, material and conceptual approach, which today is institutionalized as a distinct field, with its own educational system and regulatory mechanisms. At the same time, duodji is part of everyday life in many households, both as concrete, functional objects, being worn and used, and as tacit knowledge and way of life, transferred between generations and through other informal networks (e.g. Guttorm 2013; Fors 2019). A quick search for the word duodji in a museum database, such as DigitaltMuseum, which includes images from a variety of museums in Norway and Sweden, reveals an abundance of complex and beautiful items, traversing confines associated with art, craft, fashion and design, just to mention a few intersections negotiated in an institution like the Museum of Decorative Arts and Design.

Until the museum closed in 2016, it showed the permanent exhibitions Style 1100-1905, Design and Craft 1905-2005, The Costume Galleries and The Collections for Glass and Ceramics. In general, the displays can be conceptualised as aesthetic presentations. Lighting and arrangements accentuate the shape and style of the objects, rather than focusing on geographical, historical, or cultural contexts. Still, designations like "Norway", "Nordic", "Scandinavia" and "Europe", crop up repeatedly in wall texts and explanatory signs, even though such informational devices are often reserved to a minimum. Sometimes more specific terms for localisation are used, for example, a carved tankard is labelled as coming from the farm Klognes in Våga, in the region of Gudbrandsdalen.

This is one of the mountain valleys attracting 


\section{Monica Grini}

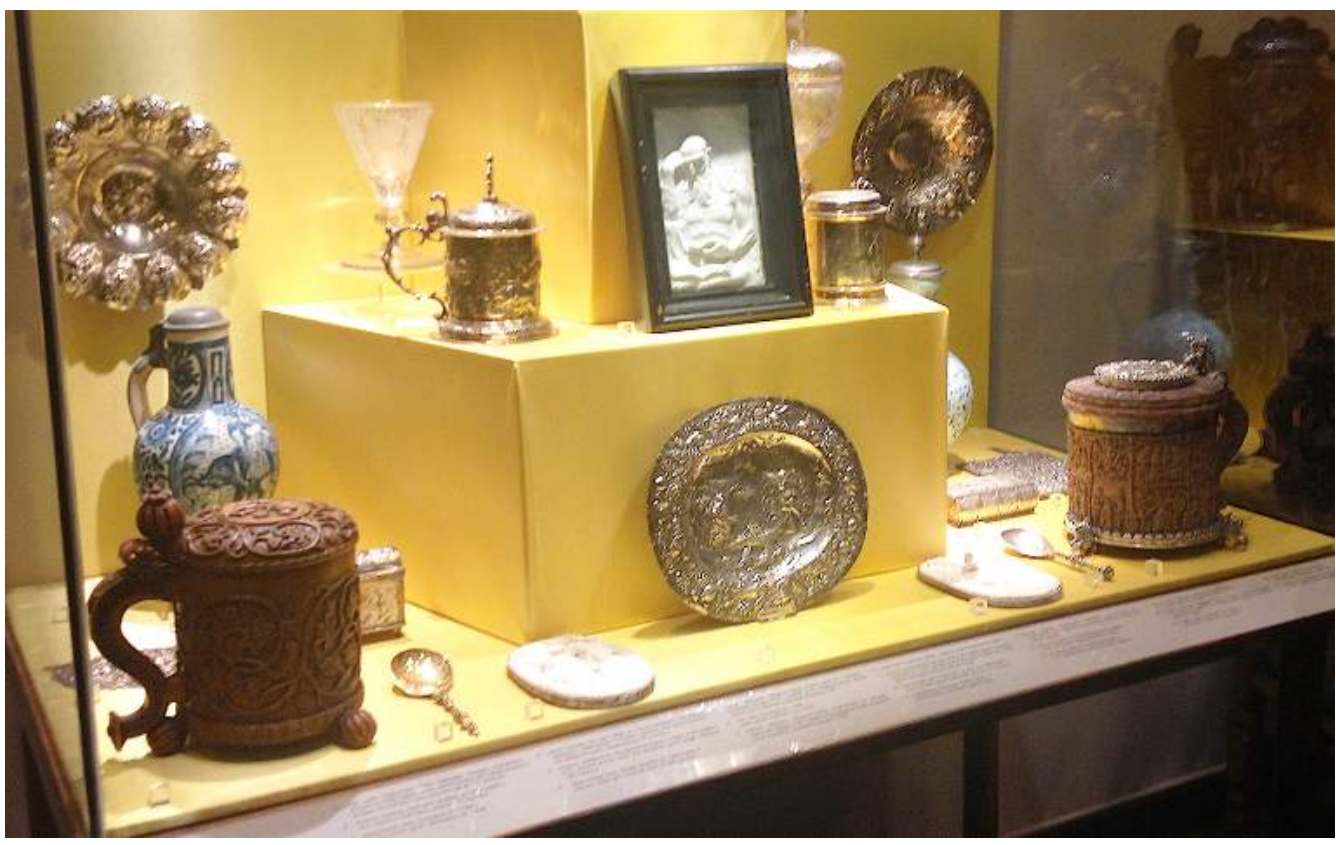

Fig. 3. Installation view from the exhibition Style 1100-1905, 2016. The National Museum of Art, Architecture and Design, Oslo. Photo: Monica Grini.

19 th and early 20th century artists, scientists, and collectors searching for inland pockets of "Norwegian culture." Lying on the ancient east-west route mentioned in Heimskringla, the old Norse kings' sagas, the area was seen as one of the places conveying "Norwegianness." The focus in this exhibition, though, is not on a contextualisation of "Norwegian culture", but rather on relating the "style history of Norway" to that of Europe, as one of the wall texts explains. The tankard is described as an example of "Nordic baroque." And indeed, it might be relevant to categorize the object like this; it can be seen as a translation of an established prototype, the baroque silver tankard and its curved pattern, into wooden material. Such objects fell out of fashion amongst the upper classes of 18th century Europe, but their popularity continued in rural parts of Norway.

Are items from the Sámi area included in this "style history of Norway"? That is, in a state "founded upon the territories of two peoples - the Norwegians and the Sámi", as king Harald acknowledged in a speech to the Sámi Parliament more than 20 years ago (e.g. Bååstede 2012:13). As among others, Maja Dunfjeld has showed, Sámi material stands in interesting and complex relationships with different historical, stylistic and ornamental traditions; for example visible through the use of gothic type Mary and Anne-monograms in Sámi horn carvings or through the use of what is identified as predominantly Sámi colouring techniques for highlighting ornament patterns in archaeological findings outside Sápmi (Dunfjeld 2006:64-65, 180-181) 
Sápmi was never an isolated enclave, but a geographically diverse area with intricate communication and exchange systems, and such complexity is reflected in the material flow of the region. For example, Phebe Fjellström examines how the category "Sámi silver" came about as a result of the multifaceted trade society during the 16 th and 17 th centuries (Fjellström 1962). She discusses how profits from trade with precious animal skin, stockfish, and various reindeer products materialized in the form of silver spoons, heavy silver cups, and jewelleries. The objects were made to order for Sámi customers in places like Bergen and Gällivare; the silversmiths adjusting the products upon request, in many cases making the silverware more solid and practical to handle, in accordance with a nomadic lifestyle.

The term "Sámi silver" figures prominently, also in contemporary Sámi design, epitomized for example by the jeweller Juhls, in Kautokeino. Sámi fashion week has been going on for years, and the Sámi University College of Applied Sciences offers bachelor and master programs in duodji; nevertheless, it was first when I reached the costume galleries on the top floor that I was met with a reference to Sámi matters in the national museum for decorative arts and design, in a room dedicated to the Norwegian fashion designer Per Spook. Some of the outfits from the collection From Paris to the Polar Circle (1989-1990), were "inspired by Sámi clothing traditions", the wall text explained. Thus, Sámi tradition was only met by secondhand reference, as inspiration, not by actual examinations. The absence of duodji reflects the collection as a whole, there are no records of duodji, or other Sámi terms in the collection, although there are indications that there have at some point been a few Sámi items in the collection, however, it is not an easy task to identify them. ${ }^{4}$
Perhaps surprisingly, the establishment 177 which has dealt most extensively with works related to duodji amongst the national art institutions of Oslo, is arguably the Museum of Contemporary Art. It has done so in an indirect way, through the works of Iver Jåks. Jåks was a multifaceted artist. He worked in a variety of materials, with a variety of techniques. In addition to his education from the art academy and the college of art and design, he was trained as a duojár, an expert in working with duodji. In his later work, this expertise comes to the fore as a material and epistemological attitude, and not necessarily through concrete objects easily recognised as duodji in a categorical sense. Rather, it is about the material chosen, especially organic material, like bone, antler and wood, and how it is assembled and handled (e.g. Snarby 2019). His work negotiates stringent demarcations between, for example, art and craft, between duodji and dáidda, the Sámi word for fine art, or between art and not-art. As with the flow of the Sámi silver trade, reciprocal circuits are in play, also in Jåks' art and its reception.

In accordance with a contemporary art concept, the Museum of Contemporary Art contains a wide range of media or forms of expressions not necessarily recognisable as "fine art" in a conventional sense, that is, paradigmatically, as painting or sculpture. Still, it is necessary to emphasise that the museum has not really explored the duodji dimension, neither connected to Jåks' art nor "Sámi culture" in any other way.

\section{REPRESENTING CULTURE}

To put it simply, if you want to experience art, artefacts, and practices that are often perceived as quintessentially Sámi in the downtown Oslo museumscape, you have to turn to the 
178 ethnographic collection in the University of Oslo's Museum of Cultural History. The ethnographic collection constitutes one of the earliest museums of this kind, founded in 1853, with the Ethnographic Museum of Denmark, from 1849, as a direct precursor and inspirational source (Nielsen 1907:3).

The ethnographic exhibitions are found on the upper floors, where the permanent exhibitions America: Past. Present. Identity and Arctic: People of the Arctic and Subarctic take up the majority of the space. One of the first things encountered when entering from the neighbouring "Americas" is a construction of an "igloo" presented as the Inuit type of dwelling. Further into the room, a conical shape is clearly meant to signify a lávvu, the Sámi summer tent. Various Sámi groups, the Northern Sámi, the Lule Sámi, the Skolt Sámi, and so forth, are represented through some well-established devices of the ethnographic display. Installations in glass-cases signify individuals, using tools and wearing garments, apparently corresponding to the region and group they are made to epitomize.

The scenes are paired with wall-texts and photographs, that among other things, help validate the message of a "true" representation of a corresponding life-world (e.g. Nielssen 2014). The contrast between the formal exploration of well-lit "tools", like spoons and tankards, on display in the Museum of Decorative Arts and Design is striking, though both are equally compelling as representational devices. Duodji is explicitly, though simplistically, addressed in the ethnographic exhibition. A wall text simply states that "duodji is traditional craft, that has advanced into applied art today", while a selection of objects is mounted on the wall above, clearly not meant to be explored as aesthetic objects in the manner of the Museum of Decorative Arts and Design.

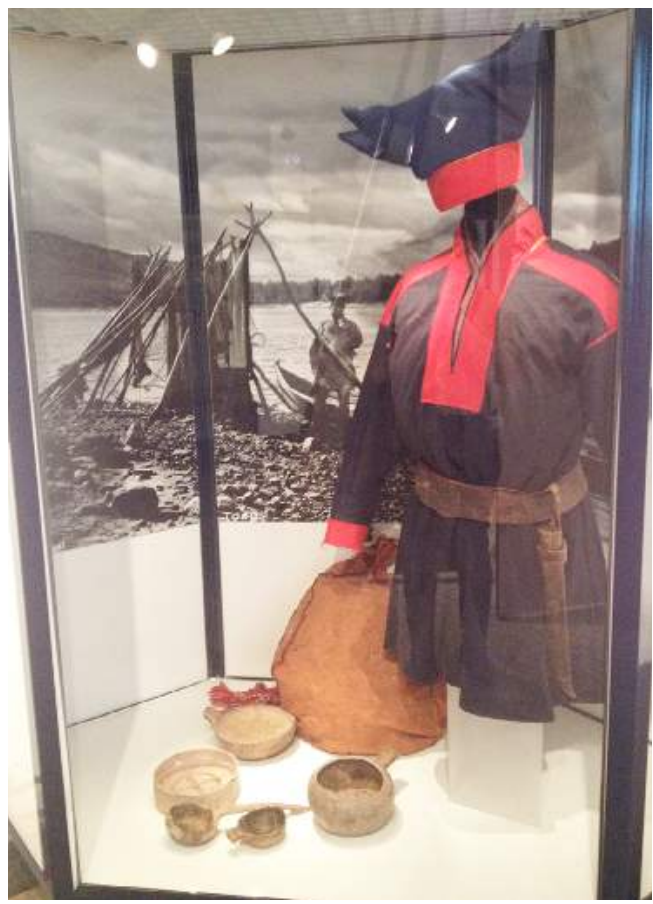

Fig. 4. Installation view from the exhibition Arctic: People of the Arctic and Subarctic, 2019. The Museum of Cultural History. Oslo. Photo: Monica Grini.

Occasionally, regional group delineations are left aside to help build and maintain others on a grander scale. "Shamanism is a common trait among the Arctic people", a central wall text states. Here, the concept of "shamanism" is articulated in an intriguing assembly of images, words and artefacts, to help support the underlying argument about the circumpolar area as one continuous space with a common, timeless "Arctic culture".

In dim lightning, a copy of a Sámi drum is hovering above a model representing the circumpolar area. The model is encircled by dark blue painted walls, covered by texts, symbols, and imageries, or by glass cabinets 
enclosing various items, dressed mannequins, and photographs taken from different regions in the vast area commonly referred to as the Arctic.

A drawing is mounted underneath the text explaining shamanism as a universal feature among arctic people, it shows an old, bearded man, beating a drum. "The Sámi called the shaman a noaidi", another text explains. The old "shaman" is surrounded by symbols taken from various drumheads in time and space, described as standing for various "gods" or other abstract entities in Sámi "religious belief", to refer to the categories preferred by the curators. On a side panel a poem is inserted, it is an excerpt from Ailo Gaup's novel, In Search of the Drum (Trommereisen). The text is written in first-person and in present tense and seems to render a so-called drum travel or the experience of ecstasy, and the revelation and knowledge achieved by such a travel. The text and the image work reciprocally upon each other, the text seem to narrate what the depicted person is experiencing, and the other way around.

Nowhere in the exhibition is the conventional "ethnographic present" (Fabian 1983) as clearly at play as in this installation. The texts are predominantly written in present tense and dates are scarcely attributed. For example, Gaup's text is from 1988, while the image is taken from Johannes Schefferus book Lapponia, from 1673, although in the display they seem to occupy the same time and space, explaining the same phenomenon. ${ }^{5}$ Seen together, the different components function to prioritize and reinforce a single narrative; that of shamanism as the same unchanging practice, containing the same elements, occupying the same arena, in every arctic society throughout time. ${ }^{6}$ As a consequence, the drums are rendered, first and foremost,

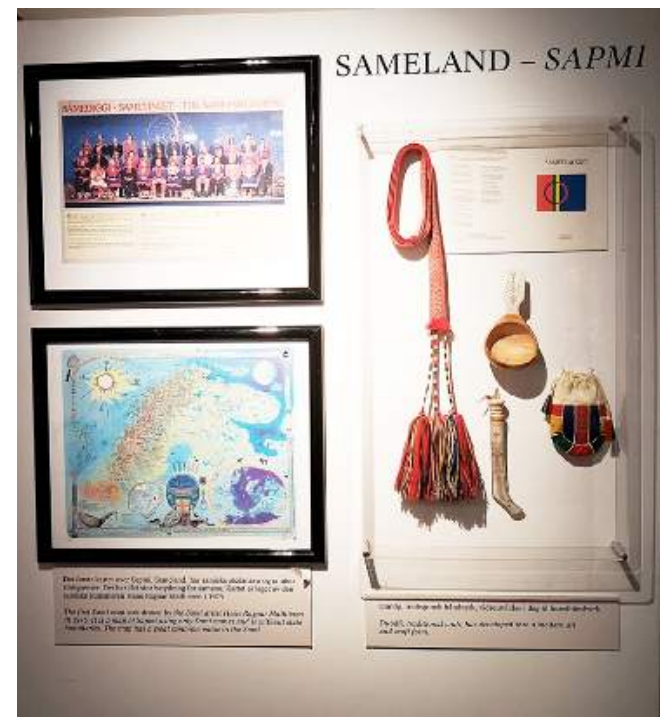

Fig. 5. Installation view from the exhibition Arctic: People of the Arctic and Subarctic, 2019. The Museum of Cultural History. Oslo. Photo: Monica Grini.

as ecstatic devices for male users, as indicated by gendered textual and pictorial strategies, notwithstanding the heterogeneity of the material, proven by a complex source material (e.g. Rydving 2010; Grini 2016; Fonneland 2018a).

Seen in an overall perspective, "the Arctic" of the ethnographic display at the Museum of Cultural History is an area without conflictzones. As a visitor one moves rather smoothly into a continuous, and rather timeless, arctic space which is not ruptured by, for example, global industrial mining companies or the territorial politics of the varied national states that intersect this enormous area. Although a larger space is dedicated to Sámi societies than to other groups represented in the exhibition, nothing profoundly testifies to the fact and frictions related to Sápmi, Sámi, Norway and Norwegian as overlapping entities and identities 
within the same national state. Although, from 2015 an important temporary exhibition, Ten Sami Time Frames. Logi sámi áigegova, has been added. The exhibition "highlights the diversity of Sápmi and presents personal portraits of people, landscapes, traditions and languages undergoing change" (Kulturhistorisk museum 2015), and is made by central actors in Sápmi, the social anthropologist, Jorunn Eikjok, and photographer, Ola Røe, in collaboration with the Sámi Museum (RiddoDuottarMuseatSámiid Vuorká-Dávvirat) in Karasjok. Still, the overall narrative in the permanent exhibition remains that "Sámi culture" equals "Arctic culture", and as something other than "Norwegian culture" or "European culture"; this is in an arctic where Norway's position as one of the chief actors in this geopolitical area remains invisible.

Part and parcel to the idea that some people's "culture" belongs to the ethnography department, is the idea that there are other people whose "culture" does not belong there. During the institutional beginnings of the Norwegian national museumscape, much of the discussion was dedicated to the concern that "Norwegian national costumes" would end up exhibited among the outfits and artefacts of the "Indians or the South Pacific Wilds" (Undset 1885:11-12, my translation). ${ }^{7}$

After a while a "folk museum", the Norwegian Museum of Cultural History, materialized on the Bygdøy peninsula. From the beginning, it was envisioned as a place to represent "the nation's own culture" (e.g. Aall 1920). Sámi items, apparently not considered the "nation's own", were not included among the re-erected buildings and costumes and belongings transported from the Norwegian countryside. Sámi items were not included here before the 1950s, when the director of the Ethnographic Museum, Gutorm Gjessing, took the initiative to move parts of the Sámi collection there. The intention was, he stressed, that Sámi citizens should be placed on equal footings with other citizens, and not continue to be treated as foreigners in their own country (Pareli 2004:36-37). Today, there is a Sámi department at the museum. Sámi dwellings, from Hedemark, in the southernmost part of Norwegian Sápmi, are included in the openair museum, and there is a permanent indoor exhibition, Sámi Culture.

This exhibition is divided in two distinct parts. It represents the "Sámi way of life in the past and in modern times", the museum states (Norsk folkemuseum 2019). The emphasis is on the past, and it especially centres around that which is explained as traditional livelihoods; hunting, farming, and herding. Here objects related to duodji are presented in dioramas, and contextualized as parts of the old-style life-world. Duodji, in this sense, encompasses first and foremost traditional techniques for processing products connected to husbandry and reindeer herding. Whereas in the part that is meant to represent "modern times", Sámi art, duodji, dáidda are presented as belonging to distinct and specialised fields of the contemporary society. The focus is mostly to present this as important elements in Sámi society today, as parts of the revitalization process that took hold since the 1980s, and not on exploring and interpreting the pieces as artworks in themselves.

\section{REVISITING THE ART-CULTURE SYSTEM}

More than thirty years have passed since James Clifford famously diagrammed the artculture system to help apprehend how objects are classified, granted relative value, and incorporated into different sites and circuits. It is beyond the scope of this article to discuss the 


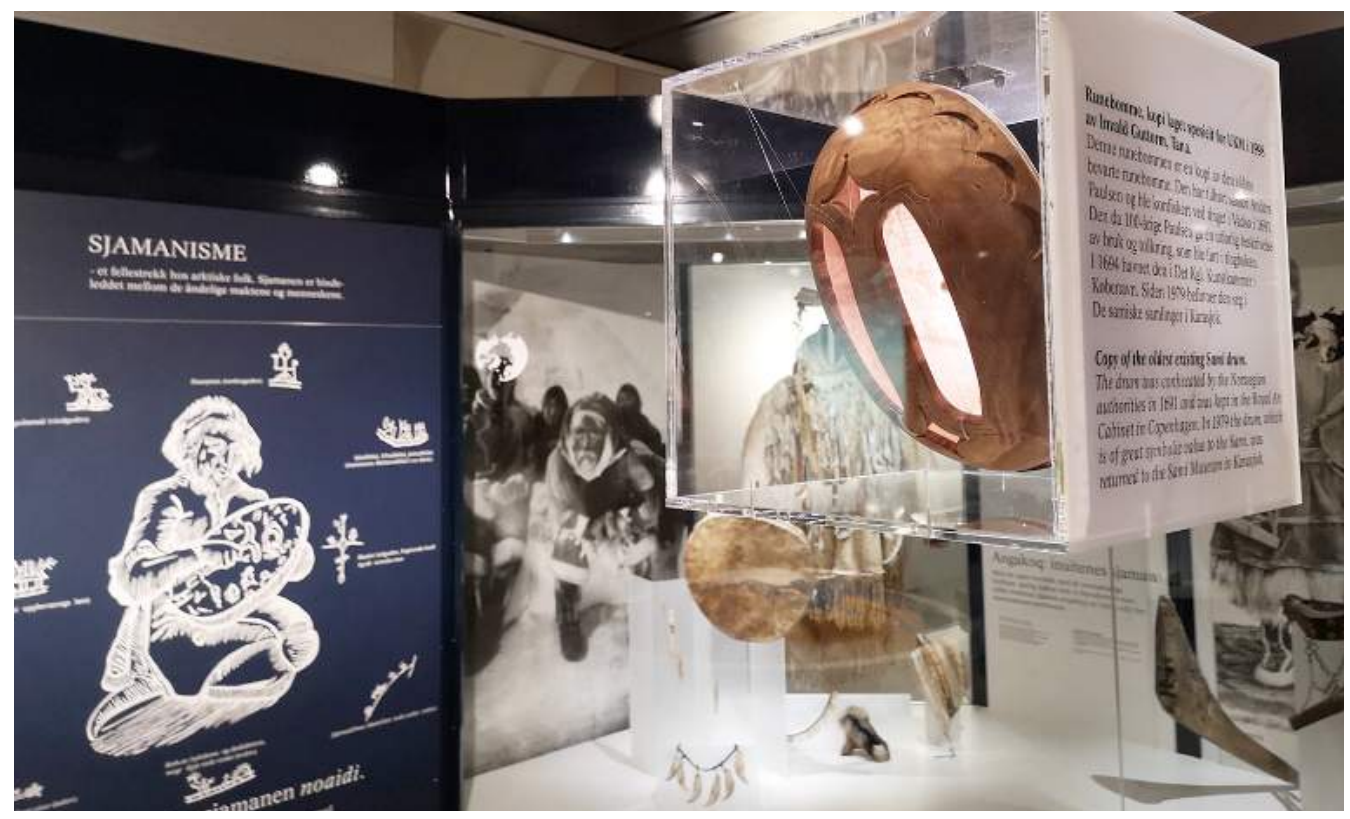

Fig. 6. Installation view from the exhibition Arctic: People of the Arctic and Subarctic, 2019. The Museum of Cultural History. Oslo. Photo: Monica Grini.

finer details of Clifford's model, but generally speaking, it sketches out the ethnographic museum and the art museum as complementary classificatory modes and valuators, starting with the two major categories "works of art" and "cultural artefact" to generate a larger field of terms, meanings, and circuits (Clifford 1988:222-228). The structure seems to echo the antithesis outlined in the beginning of this text, between the humanist and anthropological use of "culture", where the former points to "art" in a narrow sense, the latter points to "culture" in a broad sense. The main difference being that while the first articulates novelty and singularity, the uniqueness of the object and its maker, the second highlights custom and collectivity, the object and maker's relation to a larger society. There is frequent traffic between the two categories, functional items, collective in their roots, like tankards and spoons, can be exhibited in a way that highlights them as "art", and individual art works, like Savio's woodworks, can be contextualized according to their apparent relation to a certain collective. One of Clifford's points was that objects from societies perceived as "non-Western" tended to be regulated into the ethnographic museum, whether made by artists, or represented as "art" or "culture."

The point by evoking the art-culture system here is that despite critical claims and radical changes in the museum sector since Clifford wrote his article, the model still seems remarkably to the point when it comes to Sámi representation in the Oslo museumscape. To summarize, Sámi matters are predominantly articulated as "culture" in the anthropological sense in this museumscape. Whether treated 
182 as duodji, dáidda, “art”, or "artefacts", Sámi objects continue to be represented, first and foremost, by museums of cultural history, and more specifically - as the exhibition in the University of Oslo's Museum of Cultural History testifies - as ethnographic material. Even though the National Museum of Art, Architecture and Design holds works by significant Sámi artists, and works signifying Sámi themes, to date, it has not exhibited these in a way, or to an extent, that contributes to rupturing the prevailing "national imaginary" in any significant way. Moreover, a special case has to be made for the area of duodji, which has yet to be explored by the art historical museum, but remains a naturalized part of the ethnographic department.

Sámi objects were among the basis for the collection when the Ethnographic Museum first opened its doors (e.g. Mathisen in this volume) and it seems clear that this manoeuvre can be seen in light of the accelerating Norwegianization politics at the time (Grini 2016:52-104). Sámi issues were regulated into a distinct sphere, to the representational space for the foreign "others", a manoeuvre which, among other things, helped clear the way for the production of the conceived "national unity", without a competing narrative of the "other" within. ${ }^{8}$ Museums help producing, maintaining, and naturalising certain kinds of citizenships. The politics of the organisational and physical divide, practically moulded in the museological layout of the capital city from the beginning is quite obvious: in simple terms, the division is between the art museum showing "European" and "Norwegian" arts, or culture, and the Ethnographic Museum, showing the arts, or culture, of "the rest." Significantly, they are both situated inside the geographical "axis of power" in the city plan.

To be fair, the situation should not be taken to be the same today as it was more than 100 years ago - even though the slow transformation suggests ongoing investments in the narrative of Norway as a monocultural nation. Still, it does not automatically follow from the fact that the ethnographic department has remained the most visible museum space for Sámi matters in the immediate city centre, that this points to the exact same thing as when the museum was established. As stated above, museums have long been under critical scrutiny, precisely because of such intrinsic biases and connectedness to governance that I have been trying to flesh out in this article. Even though such critical museology is not immediately visible in the current Arctic-exhibition, there has been attempts to reconsider the exhibitory form, for example, through the temporary exhibition NewArctic, where Arctic research experts experimented with "new ways of exhibiting the Arctic" (Kulturhistorisk museum 2018). Also, Ten Sami Time Frames has clearly been added to provide an update to the Arctic exhibition. ${ }^{10}$

Even more significantly, as testified by Ten Sami Time Frames, the Sámi political situation is radically different today than a century ago. Sápmi hosts three Sámi parliaments, although predominately ruled by the Norwegian, Swedish, and Finnish governments, the Sámi people in the different national-states are represented by their own parliamentarian institutions. Importantly, as the Bååstede-report demonstrates, a Sámi museum system has been formed, embodied by six museum units under the authority of the Sámi Parliament in Norway. In short, today there is a distinct Sámi representational system, overlapping and reconfiguring the dominating governmental representational system.

Despite these transformations, and to return to the initial cue from the Bååstede- 


\section{SÁMI (RE)PRESENTATION IN A DIFFERENTIATING MUSEUMSCAPE: REVISITING THE ART-CULTURE SYSTEM}

report, it is difficult to argue that a "good and representative presentation of Sámi culture" is to be found in central Oslo today, at the very least, because such profound changes are only visible to a minor degree in the current museumscape.

\section{Notes}

1. Of course, a third demarcation can be made, concerning the biological use, as in "culture of bacteria" or "agriculture" and so on.

2. The Haugean movement took its name from the evangelist Hans Nilesen Hauge, practicing as a lay preacher at a time when such activity was forbidden by law. The Conventicle Act of 1741 prohibited any religious meetings not authorized by the state church. Hauge was seen as an advocate for separatism while Norway was still a part of Denmark (e.g Dørum and Sødal 2017). Laestadianism is a pietistic Lutheran revival movement, named after Lars Levi Laestadius. The movement is associated with the Kautokeino uprising of 1852, where a local merchant and the district sheriff ended up being killed, whereas two of the leaders of the movement were punished by execution by the Norwegian government (e.g. Zorgdrager 1997).

3. I counted more than 70 artworks by Savio on my last survey of the collection (Grini 2019).

4. Peder Valle, collection assistant at The National Museum of Art, Architecture and Design, personal communication, 29 September 2018 and 5 April 2019. Valle identified one of the items as an embroidered purse (collection identification number OK-06146) entering the Museum for Decorative Art and Design in 1900.

5. Gaup was trained by Michael Harner at his Californian Foundation for Shamanic Studies in the 1980s and is sometimes dubbed "the first Sámi shaman" (e.g Fonneland 2018b). Schefferus was a professor at the Uppsala University, writing at a time when Sámi drums were being deemed as devices for witchcraft by the Danish-Norwegian authorities.

6. Precisely because of its efficacy in ruling out other stories, historians of religion have long opposed to the use of shamanism as a generic term. Olle Sundström highlights that the concept "originally belongs to the 'colonizers' conceptual tool-box", the term is supposed to have its origin from an Evenki word, but as generic term it was created by outsiders to the indigenous societies they sought to study (Sundström 2015:76-77). Importantly, such reservations are made against the use of the concept as a general term, it does not devaluate the use of shamanism to describe a historically and culturally situated phenomenon, like for instance contemporary shamanism (e.g. Sundström 2015; Fonneland 2017).

7. Consult Grini 2016:84-104, for more in this debate.

8. I borrow the phrase "the 'other' within" from Varutti 2011.

9. It is important to note that this is a broad generalization, made for the clarity of the argument, as I have discussed above, there were from early on artworks with Sámi references in the National Gallery's collection, although they have not been constructed as the canonical works of the collection. On the other hand, the observation that duodji has remained a blind zone for the Museum of Decorative Arts and Design strongly testifies to such a claim.

10. Such interventions are also visible through added elements to the original Arctic exhibition, for example on my latest visit, in august 2019, a printout was mounted on the glass-case containing the copy of the drum, giving a cursory reference of the history of the original drum and the copy. 


\section{LITERATURE}

Aall, Hans 1920. Norsk folkemuseum, 1894-1919.

Trekk av dens historie. Kristiania: Kirstes boktrykkeri.

Bennet, Tony 2015. "Cultural studies and the culture concept." Cultural Studies 25:4, 546-568.

Blaser, Mario 2009. "Political ontology." Cultural Studies, 23:5-6, 873-896.

Butenschøn. Peter 2015. "Nasjonsbygging og hovedstad." Aftenposten. https://www.aftenposten. no/osloby/i/bro5/Nasjonsbygging-og-hovedstad (accessed 4 July 2019).

Bååstede. Tilbakeføring av samisk kulturarv 2012. Karasjok/Oslo: Sametinget, Kulturhistorisk museum, Norsk folkemuseum.

Clifford, James 1988. The Predicament of Culture: Twentieth-Century Ethnography, Literature, and Art. Harvard: Harvard University Press.

Clifford, James 2013. Returns: Becoming Indigenous in the Twenty-First Century. Harvard: Harvard University Press.

Cobley, Paul 2008. "Culture. Definitions and concepts." In Wolfgang Donsbach \& Paul Cobley (eds.). The International Encyclopedia of Communication. Malden: Blackwell. https://doi. org/10.1002/9781405186407.wbiecc173.

Dunfjeld, Maja 2006. Tjaalehtjimmie. Form og innhold i sørsamisk ornamentikk. Snåsa: Saemien sijte.

Dørum, Knut \& Sødal, Helje Kringlebotn (eds.) 2017. Hans Nielsen Hauge. Fra samfunnsfiende til ikon. Oslo: Cappelen Damm Akademiske.

Fabian Johannes 1983. Time and the Other. How Anthropology Makes its Object. New York: Columbia University Press.

Fjellström, Phebe 1962. Lapskt silver. Studier över en föremålsgrupp och dess ställning inom lapskt kulturliv. Stockholm: Almqvist \& Wiksell.

Fonneland, Trude 2017. Contemporary Shamanisms in Norway. Religion, Entrepreneurship, and Politics. Oxford: Oxford University Press. Fonneland, Trude 2018a. "Hvor var kvinnene?" In
Brita Brenna \& Marit Anne Hauan (eds.). Kjønn på museum. Trondheim: Museumsforlaget, 47-66.

Fonneland, Trude, 2018b. "Sárakka dansar." FETT. http://fett.no/sarahkka-dansar/ (accessed 25 September 2019).

Fors, Gry 2019. "Duodji as a starting point for artistic practice." 24 April 2019. https://www. norwegiancrafts.no/articles/duodji-as-a-startingpoint-for-artistic-practice (accessed 5 July 2019).

Gaski, Harald \& Berg-Nordlie Mikkel 2019. "Samer." Store Norske Leksikon. https://snl.no/samer (accessed 25 June 2019).

Grini, Monica 2016. Samisk kunst i norsk kunsthistorie. Historiografiske riss. Doctoral thesis. Tromsø: UiT Norges arktiske universitet.

Grini, Monica \& Oskal, Nils 2018. "Fra Karesjok, Tana-elv og Vadsøe Sogn i Sommerdragt. Resepsjonshistorikk og tolkningsmuligheter." DIN. Tidsskrift for religion og kultur, 2, 88-99.

Grini, Monica 2019. "Så fjernt det nære.

Nasjonalmuseet og samisk kunst." Kunst og kultur, 3. http://dx.doi.org/https://doi.org/10.18261/ issn.1504-3029-2019-03-04.

Grossberg, Lawrence 1986. “On postmodernism and articulation. An interview with Stuart Hall." Journal of Communication Inquiry, 10:2, 45-60.

Guttorm, Gunvor 2013. "Paradigm shift in the view of duodji in the 21th century. Higher education in duodji." Taiwan Journal of Indigenous Studies, 6:3, 119-138.

Hvattum, Mari 2017. "Drømmen om et Nasjonalgalleri." In Audun Eckhoff (ed.). Nasjonalgalleriet. Bergen: Fagbokforlaget.

Høydalsnes, Eli 2003. Møte mellom tid og sted. Bilder av Nord-Norge. Oslo: Forlaget Bonytt.

Kulturhistorisk museum 2015. "Ten Sami Time Frames. Logi sámi áigegova." https://www.khm. uio.no/english/visit-us/historical-museum/ temporary-exhibitions/2015/ten-sami-timeframes.html (accessed 19 August 2019).

Kulturhistorisk museum 2018. "NewArctic." https:// www.khm.uio.no/english/visit-us/historical- 


\section{SÁMI (RE)PRESENTATION IN A DIFFERENTIATING MUSEUMSCAPE: REVISITING THE ART-CULTURE SYSTEM}

museum/temporary-exhibitions/2016/newartic. html (accessed 30 September 2019).

Latour, Bruno 1993. We Have Never Been Modern. Harvard: Harvard University Press.

Macdonald, Sharon 2016. "New constellations of difference in Europe's 21st-century museumscape." Museum Anthropology, 39:1, 4-19.

Mathiesen, Silje Oppdahl 2019. "A record of ethnographic objects procured for the Crystal Palace in Sydenham." Nordic Museology 3, 8-24.

Najonalmuseet 2019a. "The dance of life. The collection from antiquity to 1950." http:// www.nasjonalmuseet.no/en/exhibitions_ and_events/exhibitions/national_gallery/ The + Dance + of + Life +-+ The + collection + from + a ntiquity+to+1950.9UFRnY1E.ips (accessed 5 July 2019).

Nasjonalmuseet 2019b. "Highlights. Art from antiquity to 1945." http://samling.nasjonalmuseet. no/en/object/NG.M.01219 (accessed 5 July 2019).

Norsk folkemuseum 2019. "Sámi culture.” https:// norskfolkemuseum.no/en/sami-culture (accessed 30 September 2019).

Nielsen, Yngvar 1907. Universitetets ethnografiske samlinger 1857-1907. En historisk oversigt over deres tilblivelse voekst og udvikling. Christiania: W.C. Fabritius og sønner AS, 1907.

Nielssen, Hilde 2014. "Photography and the crisis of ethnographic display." In Elizabeth Edwards \& Sigrid Lien (eds.). Uncertain Images. Museum and the Work of Photographs. Farnham: Ashgate, 55-72.

Pareli, Leif 2004. "En gamme blant nasjonalskattene. Om samenes skiftende plass ved Norsk Folkemuseum.” In Trond Bjorli, Inger Jensen \& Espen Johnsen (eds.). Museum i friluft. Oslo: Norsk Folkemuseum, 32-45.

Rydving, Håkan 2010. Tracing Sami Traditions. In Search of the Indigenous Religion among the
Western Sami during the 17th an 18th Centuries.

Oslo: Novus.

Smith, Anthony D. The Nation Made Real. Art and National Identity in Western Europe, 1600-1850. Oxford: Oxford University Press.

Snarby, Irene 2019. "Duodji as indigenous contemporary art practice." 23 April 2019. https://www.norwegiancrafts.no/articles/duodjias-indigenous-contemporary-art-practice (accessed 5 July 2019).

Stocking, George W. 1966. "Frans Boas and the culture concept in a historical perspective." American Anthropologist, 68:4, 867-882.

Sundström, Olle 2015. "Shamanism, politics and ethnos-building in Russia." In Greg Simons \& David Westerlund (eds.). Religion, Politics and Nation-Building in Post-Communist Countries. Farnham: Ashgate, 75-98.

Undset, Ingvald 1885. Om et norsk national-museum. Kristiania: Cammermeyer.

Varutti, Mariza 2011. "Gradients of alterity. Museums and the negotiation of cultural difference in contemporary Norway." Arv. Nordic yearbook of folklore, 67, 13-36.

Zorgdrager, Nellejet 1997. De rettferdiges strid. Kautokeino 1852. Samisk motstand mot norsk kolonialisme. Oslo: Norsk Folkemuseum/Vett \& Viten

Monica Grini, PhD in Art History. Senior Lecturer in Media and Documentation Studies, monica.grini@uit.no

Department of Language and Culture, UiT - The Arctic University of Norway P. O. Box 6050 Langnes 9037 Tromsø, Norway 